\title{
Mulheres intelectuais em trânsito na América Latina nos séculos XIX e XX: Maria Concepcion Gimeno Flaquer e Margaret Randall
}

\author{
Cristiane Ribeiro ${ }^{1}$ \\ Stella Ferreira Gontijo ${ }^{2}$
}

Resumo: Por intermédio das trajetórias de Maria Concepcion Gimeno Flaquer e Margaret Randall, busca-se pensar a circulação de mulheres intelectuais na perspectiva transnacional. As fontes de análise foram as revistas, produções importantes para colocar vozes silenciadas em circulação no espaço público, bem como para mantê-las em contato umas com as outras. Interessa-nos, com isso, revelar vestígios que comprovem que desde o século XIX, as trocas entre o Norte e o Sul Global foram uma constante, propiciando que experiências fossem compartilhadas, sendo as mulheres importantes atores nessa relação. As duas intelectuais elegidas situam-se em contextos distintos, séculos XIX e XX, recorte temporal que se justifica pelo fato de que a análise em larga escala possibilitou afirmar que os espaços intelectuais latino-americanos contaram com uma importante participação feminina, construídos e compartilhados com o intuito de criar redes, apoios e sociabilidades. Tudo isso, analisado conjuntamente, reflete as desigualdades de gênero estruturadas historicamente na vida das mulheres e o silêncio historiográfico de suas produções.

Palavras-chave: Mulheres intelectuais; Estudos de Gênero; América Latina.

\section{Intellectual women in transit in Latin America in the $\mathrm{XIX}$ and $\mathbf{X X}$ centuries: Maria Concepcion Gimeno Flaquer e Margaret Randall}

\footnotetext{
${ }^{1}$ Doutoranda em História pela Universidade Estadual de Campinas (UNICAMP), com pesquisa intitulada "Giz, penas e impressos: o universo do trabalho intelectual feminino no Rio de Janeiro". Bolsista do Conselho Nacional de Desenvolvimento Científico e Tecnológico $(\mathrm{CNPq})$ e atualmente leciona como professora substituta no Centro Federal de Educação Tecnológica de Minas Gerais (CEFET/MG). Pesquisadora Associada do Núcleo de História Social da Política (NEHSP/UFJF), na linha de pesquisa "Mulheres e a escrita da História", do Grupo de Pesquisa Gênero e História (GRUPEG/USP) e do Núcleo de Estudos da Edição, Literatura e Imprensa (NEELIM/UNICAMP). Orcid: 0000-0002-5177-2807. E-mail para contato: crisdepaularibeiro@hotmail.com

${ }^{2}$ Doutoranda no Programa de Pós-Graduação em História da Universidade Federal de Minas Gerais (UFMG), com pesquisa intitulada "Produção intelectual e trajetória de Margaret Randall: o debate transnacional de uma teoria política feminista latino-americana (1962-1984)". Bolsista do Conselho Nacional de Desenvolvimento Científico e Tecnológico (CNPq). Graduada em História pela mesma instituição (2015). Mestre em História pela Universidade Federal Fluminense (2019/UFF). Pesquisadora do grupo "História Intelectual: narrativas, práticas e circulação de ideias" (UFMG), do Núcleo de Pesquisa em História das Américas (NUPHA/UFMG) e do Núcleo de Estudos sobre Exílio e Migrações (NEEM/UFMG). Foi pesquisadora do "Projeto República: centro de pesquisa, documentação e memória" (2017-2019/UFMG) e professora substituta do Colégio de Aplicação João XXIII na Universidade Federal de Juiz de Fora (2019-2021/UFJF). Atualmente é Vice-presidenta da Associação Nacional de Pós-Graduandas/os (ANPG 2020-2022). E-mail para contato: sfgontijo@gmail.com
} 


\begin{abstract}
Through the trajectories of Maria Concepcion Gimeno Flaquer and Margaret Randall, we aim to reflect about the circulation of intellectual women in a transnational perspective. For this purpose, we used magazines as historical source, regarded as important productions where silent voices could circulate in the public space and an important element to keep people in contact. We seek to find traces pointing that since the XIX century, exchanges between the Global North and South were constant, providing shared experiences. In this regard, women's activities were essencial. Both the intellectuals lived in different contexts, in the XIX and XX centuries, a timeframe chosen due to its large scale, which may assist us in proving that the actions of intellectual women counted with an important women participation. They created, while sharing the intellectual space, some networks, relationships, sociabilities etc. All of this can be analized toghether revealing a historical gender inequality and the historiographic silence of their productions.
\end{abstract}

Keywords: Intellectual women; Gender Studies; Latin America.

\title{
Artigo recebido em:
}

Artigo aprovado para publicação em:

\section{Introdução}

Ao analisarmos as trajetórias de vida e intelectual de duas mulheres que escolheram viver e atuar na América Latina - a espanhola Maria Concepcion Gimeno de Flaquer e a estadunidense Margaret Randall -, temos como objetivo pensá-las enquanto intelectuais, refletindo sobre as formas que encontraram para romper com os padrões de gênero estabelecidos e, a partir daí, contribuíram para a conformação de um pensamento de sua época e para a formação de redes intelectuais, principalmente por meio de suas atuações em jornais e revistas nos dois últimos séculos, seus períodos de atuação. Assim, acreditamos cooperar com a renovação e a inclusão de novos sujeitos na narrativa historiográfica. Para isso, partimos principalmente das discussões propostas pelas epistemologias feministas que, juntamente aos estudos de gênero, têm se 
colocado, nas últimas décadas, como alternativas teórico-metodológicas ${ }^{3}$ fundamentais para produção de novos saberes, novos sujeitos e de novos olhares, por muito tempo ignorados.

Quando falamos em América Latina, por seu turno, um importante aporte são as categorias desenvolvidas pelas/os teóricas/os decoloniais ${ }^{4}$, que buscam refletir sobre as características dos territórios colonizados, sobretudo na vida das mulheres, e que nos coloca especificidades no que tange à análise desses sujeitos históricos, questionando as narrativas construídas até então e refletindo sobre outras possibilidades epistemológicas. Com isso posto, a escolha por ambas provém de questionamentos que surgiram a partir de nossos objetos de pesquisas e de trocas acadêmicas constantes, momento em que percebemos que a questão da intelectualidade feminina - e feminista - é algo que atravessa grande parte do território e da história latino-americana, não estando centrada em determinada região ou, muito menos, em certo período histórico. Claro que, com isso, não estamos nos furtando da complexidade de se debater a participação e formulação teórica dessas mulheres, historicamente excluídas da historiografia.

Maria Concepcion Gimeno Flaquer e Margaret Randall são as duas personagens centrais deste trabalho. Mulheres do Norte Global que nasceram em séculos distantes, XIX e XX, respectivamente, mas que escolheram, igualmente, atuar e compartilhar suas produções com as companheiras e os companheiros da América Latina, contribuindo para que a conformação de identidades, juntamente ao compartilhamento de intelectualidade, obtivesse circulação transnacional. As trajetórias dessas duas mulheres também ajudam a complexificar o fato de que muito do que ambas produziram circulou na Europa, o que corrobora com o debate sobre o pensamento de fronteira proposto por Walter Mignolo (2008). No caso das mulheres, a situação se enreda ao pensarmos que estas foram excluídas sistematicamente dos espaços institucionais catedráticos da produção do conhecimento, tais quais as associações de classe, as academias, os

\footnotetext{
3 Esses estudos começam a ser pensados, inicialmente, no campo da História das Mulheres na década de 1960, tendo nomes como Gerda Lerner, Michelle Perrot, Louise Tilly, entre outras. Na perspectiva dos Estudos de Gêneros, passa a ser considerada, principalmente depois do referenciado artigo "Gênero: uma categoria útil para análise histórica", da estadunidense Joan Scott, publicado originalmente em 1990.

${ }^{4}$ Dentre os quais destacamos: Aníbal Quijano, Maria Lugones, Oyéronké Oyeyumi, Rita Segato, Walter Mignolo.
} 
cursos e as universidades. Também estiveram excluídas da narrativa da História e, por muito tempo, estiveram ausentes enquanto sujeitas, já que estão ausentes daquelas que foram, por muito tempo, consideradas como fontes oficiais.

O século XIX pode ser visto como um momento notável, tendo em vista o contexto de ebulição das incipientes ideias feministas, sobretudo por meio de publicações literárias, fossem por meio de obras, jornais ou revistas. Já no século XX, deparamo-nos com um período de efervescência do movimento feminista no Norte global e dos movimentos de esquerda latino-americanos, circunstância em que as mulheres já atuavam política e intelectualmente nos debates e formulações da época, inseridas em contextos revolucionários que colocavam no panorama a possibilidade de construção de novas sociedades. Contudo, na historiografia, nos diversos tempos históricos e nos processos citados, encontramos pouca presença dessas mulheres e de suas contribuições. Essa ausência não diz respeito à pouca ou inexistente atuação destas, mas sim de um vácuo que insiste em silenciar a presença e as contribuições femininas nos processos históricos.

Sendo assim, o que justifica o recorte temporal estabelecido, finais do século XIX até meados do $\mathrm{XX}$, é a tentativa de exemplificar, a partir das duas trajetórias, como a intelectualidade produzida por mulheres esteve presente desde os últimos séculos e, igualmente, como o papel das revistas foi substancial para que atuassem e colocassem suas vozes, e de outros sujeitos subalternizados, no mundo. As revistas, a literatura e as artes são por si só fontes históricas que nos dão acesso privilegiado às experiências das mulheres, e acreditamos que podemos contribuir ao inseri-las na historiografia sobre a intelectualidade, buscando compreender as diferentes formas encontradas por essas mulheres para atuarem por meio das revistas culturais, em diferentes períodos.

As batalhas travadas por mulheres intelectuais são longínquas, em que buscaram diversas estratégias para que assegurassem alguma forma de atuação no espaço público. Nos séculos passados, era comum que muitas se sentissem sozinhas, uma vez que as condições coercitivas de gênero não lhes propiciavam o acesso aos mesmos espaços que os homens. No século XIX, por exemplo, a maioria das intelectuais lutava sozinhas e o isolamento era sentido como 
enfermidade, alienação e loucura. Por isso, a maioria delas procurava um apoio e um modelo numa antecessora, dando origem a um 'sororato' destacado pelas críticas feministas." (TELLES, 1992, p. 55). Ainda hoje, essa prática é bastante comum nos movimentos feministas e intelectuais, recordar as antepassadas que lutaram por uma sociedade mais justa e igualitária, fazendo com que suas vozes sejam lembradas no presente.

Nessa lógica, as mulheres do século XIX buscaram referenciar-se em nomes que, paulatinamente, vinham alcançando notabilidade no âmbito intelectual, fosse ao publicarem obras literárias ou ao dirigirem seus jornais e revistas. São mais que conhecidas as francesas George Sand, Delphine de Girardin e Madame de Stael, as inglesas Jane Austen e Charlotte Bronté e as americanas Harriet Stowe e Charlotte Perkins. Essas mulheres estavam imersas em espaços ocidentais do Norte global, isto é, Europa e Estados Unidos, considerados o modelo de civilidade a ser seguido que surge com a Modernidade, além de frequentarem círculos intelectuais com grandes nomes do cânone literário de seu tempo. Segundo Gerda Lerner, “das fileiras dessas mulheres surgiram as intelectuais e pensadoras, as escritoras e artistas. Foram essas que, ao longo da história, tornaram-se capazes de nos dar uma perspectiva feminina, uma alternativa ao pensamento androcêntrico.” (LERNER, 2019, p. 274).

Em um outro universo, em solos latino-americanos, mulheres também vinham lutando para que seus textos fossem lidos, porém, as condições de circulação nunca foram as mesmas. Ainda que nesses espaços, países solapados pela colonização, as mulheres intelectuais estivessem amparadas em condições sociais e econômicas muito díspares das negras e indígenas, elas foram deveras diferenciadas por papéis de gênero e pelo embate colonial. Esse é um ponto importante ao longo deste trabalho, complexificar as condições heterogêneas da categoria "mulheres", na qual as sociabilidades travadas no âmbito letrado só foram possíveis devido às suas condições de cor, posição social e letramento, ainda que pelas margens.

Quando falamos de estudos sobre intelectuais, na grande maioria das vezes, nos deparamos com homens brancos, das classes mais altas e do Norte global, sendo marcante a ausência - e podemos ir mais além ao afirmarmos sobre o silenciamento - das mulheres. Grande parte dessa supremacia masculina no campo dos estudos sobre os intelectuais parte de uma 
compreensão generalizada de um sujeito universal, representado pela categoria homem, que seria representativo de toda a sociedade, a partir de uma suposta neutralidade do gênero masculino. Essa perspectiva não é exclusiva desse campo, mas se reproduz em todas as ciências sociais e humanas, e vem sendo combatida categoricamente pelos estudos de gênero nas últimas décadas. Em vista disso, a própria ideia de quem são os cânones das diversas áreas do saber dá pistas sobre a ausência de mulheres quando falamos em intelectuais, entendendo estes cânones como sujeitos dotados de autoridade em determinado campo do conhecimento. Mas o que faz com que essas pessoas sejam consideradas referências? É apenas a qualidade do seu trabalho ou envolve outras relações de poder desiguais estabelecidas pela sociedade Ocidental?

Para responder essas questões, recorremos a Nelly Richard (2002), quando esta afirma que a escrita é generificada a partir da masculinidade hegemônica, que limita a produção das mulheres e define a escrita masculina como neutra, impessoal e com autorização de fala em nome do universal. Assim, a exclusão das mulheres do cânone literário e intelectual se insere numa política generificada e racista. Para Mary Louise Pratt (2000), ocorre a "naturalização do cânone", que implica na exclusão da produção de alguns sujeitos: "los textos escritos por miembros de grupos sociales subordinados marginales, leídos según los códigos hegemónicos, parecerán 'carecer de una calidad que justifique su inclusión'.” (PRATT, 2000, p. 71). Na perspectiva de Pratt, os cânones, mais do que grandes nomes e obras, significam uma máquina de valor, uma relação de poder que instituiu uma ideia de verdade. Atualmente, com o avançar do campo epistemológico dos estudos de gênero, em parte como resposta aos movimentos sociais que reivindicam avanços na relação desigual entre homens e mulheres, vemos o questionamento desse padrão por muito tempo imposto.

Em vista disso, alguns indicadores são importantes para a compreensão sobre o que é ser intelectual. Segundo Edward Said, o/a intelectual é responsável por manter posições críticas diante dos acontecimentos de sua época, bem como promover discussões e reflexões a fim de desmontar consensos e enfrentando o status quo, atuando desde a esfera pública (SAID,1994). Do mesmo modo, Ângela de Castro Gomes e Patrícia Santos Hansesn (2016) apontam para a sua importância no que diz respeito à constituição de identidades culturais e nacionais, funcionando 
como mediadores culturais. Ao pensarmos essas designações sendo por muito tempo aplicadas apenas ao sexo masculino, constatamos um equívoco, tendo em vista que as mulheres foram, e ainda são, sujeitas atuantes nesse debate levantado, inclusive ao proporem discussões de grande valia para os círculos que frequentaram, como buscaremos mostrar. Contudo, ao pensarmos as intelectuais mulheres, devemos encarar de maneira crítica as definições da categoria "intelectuais", que não consideram atuações, trajetórias e experiências femininas para tais formulações conceituais e, por isso, muitas vezes se mostram insuficientes quanto a darem conta da complexidade e diversidade das mulheres atuantes.

Do mesmo modo, quando pensamos em América Latina, essas relações de poder são agravadas, de forma mais geral, devido à colonialidade do poder, do ser e do saber ${ }^{5}$, à imposição de teorias eurocêntricas em detrimento dos conhecimentos tradicionais e/ou produzidos no Sul global, e pela opressão interseccional às quais estão submetidas as mulheres ${ }^{6}$. A apropriação do conhecimento e do fazer é um dos traços fundamentais da violência colonial, ao buscar anular culturas e silenciar conhecimentos tradicionais e milenares, retirando a autonomia e a capacidade de ação desses povos, e com a imposição do patriarcado nos moldes ocidentais, relegando as mulheres ao espaço privado. Segundo Walter Mignolo (2008), a geopolítica do conhecimento se caracteriza justamente por essa exclusão do Sul global como produtor de conhecimento, somadamente à situação dos sujeitos, trajetórias e histórias como meros objetos, e não como atores e atrizes. Sendo assim, a intelectualidade latino-americana foi vista, durante muito tempo, como incapaz de desenvolver teorias úteis a partir de suas próprias realidades, servindo apenas como fornecedora de experiências e receptora de pensamentos científicos.

Sabemos, ainda, que foi graças à crítica feminista que houve uma revolução epistemológica nas formas de se produzir conhecimento. Desde as últimas décadas, cada vez mais, a epistemologia feminista, juntamente aos estudos de gênero, tem contribuído para

\footnotetext{
${ }^{5}$ Para ler mais sobre a colonialidade do saber, sugerimos o livro da CLACSO organizado por Edgardo Lander, em 2005, A colonialidade do saber eurocentrismo e ciências sociais: Perspectivas latino-americanas. Disponível em: $<\underline{\text { http://biblioteca.clacso.edu.ar/ar/libros/lander/pt/lander.html }>}$

${ }^{6}$ Para as teóricas feministas e decoloniais, as mulheres colonizadas passam a sofrer a violência patriarcal nos moldes ocidentais somadamente à violência colonial.
} 
questionar status, conceitos, teorias e métodos concebidos e destinados unicamente às experiências masculinas, heteronormativas, ocidentais e brancas, por muito tempo consideradas como universais pela historiografia. Para Margareth Rago, “Os estudos feministas inova[ra]m na maneira como trabalham com as multiplicidades temporais, descartando a ideia de linha evolutiva inerente aos processos históricos" (RAGO, 1998, p. 12), uma forma de propor novas inteligibilidades a antigos saberes. Outrossim, é importante ressaltar que o pensamento feminista também é uma teoria em formação, em que devemos necessariamente "criticar, questionar, reexaminar e explorar novas possibilidades" (HOOKS, 2020, p. 202), como, por exemplo, levando em consideração a experiência da diversidade de mulheres e suas respectivas desigualdades ao longo da história, uma vez que nem sempre as reivindicações e o acesso a determinados espaços foram iguais para todas, ainda mais ao pensarmos em países latino-americanos.

Frente a isso, é importante ponderarmos as problemáticas quanto aos cuidados necessários para uma análise que não transpareça excludente e homogênea na história sobre a luta das mulheres, sobretudo no campo intelectual, que nunca foi um enfrentamento coletivo contra todos os tipos de opressão e diferenças. As raízes do que conhecemos como feminismo iniciou-se com um grupo seleto de mulheres intelectuais brancas, letradas e de classe média alta da Europa e dos Estados Unidos - muitas insatisfeitas com a condição burguesa de domesticidade imposta em suas vidas - que começaram a escrever e publicar essas insatisfações. Segundo bell hooks:

Problemas e dilemas específicos de donas de casa brancas da classe privilegiada eram preocupações reais, merecedores de atenção e transformação, mas não eram preocupações políticas urgentes da maioria das mulheres, mais preocupadas com a sobrevivência econômica, a discriminação étnica e racial. (HOOKS, 2015, p. 194)

Quando pensamos na diversidade e nas especificidades das mulheres latino-americanas e do Sul global, um ponto que converge é a experiência colonial, que fez com que os processos históricos inerentes ao gênero fossem bastante distintos em comparação ao Norte global. Segundo Anne Mc Clinton, “as múltiplas culturas do mundo são marcadas, não positivamente pelo que as distingue, mas por uma relação retrospectiva subordinada em relação ao tempo linear 
europeu”. (MC CLINTON, 2010, p. 30). Ademais, um ponto importante a ser ponderado trata de que nenhuma nação colonizada assegurou a homens e mulheres acesso igual aos recursos do Estado e suas ramificações, ou seja, a ideia de poder nacional, ainda que com o fim das amarras coloniais, se baseou em construções prévias do poder do gênero, junto às intersecções de raça, classe, territorialidade, sexualidade. Com tudo isso, agora, analisaremos as revistas e trajetórias de Gimeno Flaquer e Randall, a fim de compreendermos de que forma contribuíram para a formação de redes intelectuais e para o pensamento gestado no período em que atuaram, partindo da complexidade do ser mulher intelectual em suas realidades distintas, na transformação do processo histórico.

Reforçamos que a escolha das duas intelectuais, localizadas em períodos históricos distintos, se deu em razão de semelhanças que nos abrem brecha para pensarmos, em larga temporalidade, como se deu a atuação das mulheres como intelectuais. Ambas originárias do Norte Global, optaram por atuar na América Latina, contribuindo para a conformação de redes intelectuais que questionaram e enfrentaram a lógica colonial dos saberes, da circulação do conhecimento, das artes e das culturas produzidas ao redor do mundo. Este enfrentamento se deu ao se colocarem no Sul Global e criarem revistas que se tornaram instrumentos de vazão para vozes subalternas, que até então eram silenciadas e vistas pela lógica colonial hierárquica. A partir dessa análise, deparamo-nos com questões comuns apontadas pelas relações de poder impostas às suas condições de mulheres, assim como percebemos diferenças que tangenciam seus diferentes períodos e debates colocados em cada momento. Desejamos, justamente com base nessas diferenças, traçar os pontos em comum dos desafios do ser mulher intelectual nos dois últimos séculos.

\section{Maria Concepcion Gimeno Flaquer e suas relações intelectuais travadas por meio do Album Ibero-Americano}

A entrada de mulheres no espaço profissional e intelectual tem raízes em uma luta histórica pela igualdade de gênero. Não obstante, muitas vozes passadas ainda são silenciadas. 
Ao longo do século XIX, a título de exemplo, momento que pode ser caracterizado como a gênese do feminismo pelo mundo, as intelectuais brancas e com formação intelectual iniciaram uma luta em protesto contra a opressão de gênero que as excluía de determinados espaços, como educação, trabalho e política ${ }^{7}$. Com isso, assumiram um papel, passando a desempenhar uma importante função social ao colocarem publicamente em disputa o questionamento acerca de quais deveriam ser as atribuições socialmente conferidas a elas. Para contestar o patriarcado vigente, por exemplo, essas mulheres utilizaram-se fundamentalmente de suas penas, escrevendo textos literários e de cunho manifesto que circularam nas páginas impressas, uma insatisfação com experiências bem específicas de vida.

Um movimento que se iniciou com a forte influência das ideias iluministas e liberais, imerso em classes bem distintas de mulheres, aos poucos foi se transformando em um enfrentamento mais direto relacionado às suas experiências, uma vez que:

[...] [elas] podiam ser objeto da razão e da observação masculinas, mas nunca seus sujeitos, jamais poderiam ser mentes reflexivas e universalizantes. Somente os homens eram vistos como formuladores ideais de conhecimento; e, entre eles, apenas os que pertenciam à classe, raça e cultura corretas eram vistos como detentores de capacidade inata para o raciocínio e a observação socialmente transcendentes. (HARDING, 2019, p. 104).

Em uma época em que os moldes vitorianos e civilizatórios percorriam o mundo, a vida doméstica e a maternidade eram de praxe nas famílias burguesas, constituindo hierarquias que privilegiavam os homens como intelectos e inferiorizava as mulheres, criando formas de opressões distintas. Para Bonnie Smith, as mulheres vinham reivindicando acesso ao universo intelectual e produzindo pelas margens desde o século XVIII, mesmo frente ao desdém masculino. As muitas intelectuais relegadas ao amadorismo profissional produziram obras históricas, filosóficas, biográficas e literárias com narrativas que nos possibilitam diversas reinterpretações do passado, muitas das quais escritas em forma de artigo para jornais e revistas

\footnotetext{
${ }^{7} \mathrm{Na}$ história do feminismo, que considera a trajetória da luta das mulheres no Norte global, esse período ficou conhecido como Primeira Onda do feminismo. Mas não podemos nos esquecer de que desde o século XVIII algumas mulheres já traziam à tona essa discussão para a arena política, como é o caso da inglesa Mary Wollstonecraft, que escreveu Reivindicação dos direitos da mulher em 1792, e Olympe de Gouges, na França, que escreveu a Declaração dos direitos da Mulher e da Cidadã em 1791.
} 
de suas épocas. Todavia, segundo Smith, "muitas vezes escolhiam assuntos históricos diferentes." (SMITH, 2003, p. 23).

Com o intuito de darmos conta desse problema histórico, apresentaremos, em um primeiro momento, a personagem Maria Concepcion Gimeno de Flaquer. Ela foi uma importante jornalista e intelectual espanhola que teceu diálogo com mulheres de diversos países da América Latina no final do século XIX e início do XX, publicando em muitos periódicos e revistas ao longo da sua vida. Nomes como as mexicanas Rufina Barragan de Toscano, Esther Tapia de Castellanos e Isabel Prieto de Landazuri, as peruanas Carolina Freyre de James, Clorinda Matto de Turner, Amália Puga e Mercedes Cabello de Carbonera, a uruguaia Adela Castell, a chilena Delfina María Hidalgo, as colombianas Soledad Acosta de Samper, Mercedes Alvarez de Flores, Lindaura Capero, a guatemalense Dolores Montenegro (PRIETO, 1993) e a brasileira Josefina Álvares de Azevedo ${ }^{8}$ figuram entre aquelas que compartilharam as produções escritas em páginas comuns com Gimeno Flaquer.

Os jornais e revistas são espaços reconhecidos de sociabilidade intelectual, fazendo com que se estabeleçam contatos, trocas e redes. Na América Latina, desde pelo menos o século XIX até os dias atuais, conformaram-se como importantes espaço de debates teóricos e políticos, dentre os quais podemos citar a rede arielista no XIX e a CEPAL, no século XX, como exemplos relevantes ${ }^{9}$. Para além disso, são locais que nos fornecem elementos para a compreensão da “realidad cultural de América Latina." (DEVÉS-VALDES, 2007, p. 29) e, por isso, acreditamos que seja fonte histórica importante tanto para analisarmos o papel conferido às mulheres na sociedade patriarcal quanto para a reescrita da narrativa histórica a partir da perspectiva das mulheres como sujeitas, analisando seus discursos, formulações e contribuições para os variados

\footnotetext{
${ }^{8}$ As relações com essa jornalista brasileira podem ser constatadas em produções nas páginas do periódico brasileiro A Família, que surge em 1888 e circula até o ano de 1894. As edições com seus textos são, respectivamente, as de número 7, 20 e 25 do ano de 1889 e 102 e 112 do ano de 1891. O jornal completo se encontra disponível na Biblioteca Nacional, em acesso virtual pela hemeroteca digital brasileira em: http://memoria.bn.br/DocReader/DocReader.aspx?bib=379034\&PagFis=1

${ }^{9}$ Para se aprofundar nesse assunto, sugerimos a leitura de DEVÉS-VALDÉZ, Eduardo. Redes intelectuales en América Latina: hasta la constitución de una comunidad intelectual. Santiago do Chile: Colección Idea; Segunda [Epoca; Instituto de Estudios Avanzados; Universidad Santiago de Chile, 2007.
} 
assuntos que estavam sendo debatidos em diferentes períodos. Por meio do estudo das revistas e dos debates estabelecidos entre diversos atores/as em redes transnacionais, podemos perceber que, essas ideias "alli van madurando colectivamente, asimilándose y ganando cédula de ciudadanía. [Assim, esses intelectuais assumem um papel], más allá del estado-nación, especialmente inserta en procesos de integración o colaboración científico-tecnológica" (DEVÉS-VALDÉS, 2007, p.36).

As contribuições intelectuais dessas mulheres permitem-nos levantar apontamentos substanciais sobre sociabilidade intelectual e um incipiente feminismo, juntamente a uma valorização profissional por seus trabalhos, ainda mais que a grande maioria teve em comum os empreendimentos literários e jornalísticos, os quais mesclavam distintos gêneros literários em suas páginas. Os grupos formados a partir de periódicos criaram relações profissionais que contribuíram para a criação de uma identidade coletiva, e as suas páginas são espaços importantes para compreendermos essa busca constante por companheiras com semelhantes aspirações, cuja pena era o artefato que as unia ao lado de suas reivindicações. Estabeleceu-se o que Telles denominou de cultura feminina, entendida como "um conjunto de ideias e modo de agir diferente da dos homens, mesmo que se defina em relação à dominante. Possui uma história distinta. [...] Essa tradição literária é produto de uma sutil inter-relação entre as influências da época.” (TELLES, 2012, p. 260).

Isso ajuda-nos a compreender as adequações de seus textos às influências e convenções patriarcais, inclusive às operações editoriais de impressão de seus jornais e revistas, uma vez que tiveram de estabelecer estratégias discursivas diversas para serem publicadas e lidas. Ainda mais que na linguagem hegemônica ocidental e universal do século XIX, aquelas que escreviam eram, muitas das vezes, categorizadas como anomalias indefiníveis, sobretudo pelo fato de que precisavam escapar das representações dos textos masculinos, que traziam em suas ficções histórias com o sexo feminino relegado apenas ao âmbito doméstico, sem quaisquer possibilidades de rompimento com essa condição. Para Lourdes Alvarado, foi por meio dos periódicos que as mulheres tiveram "a posibilidad de expresarse públicamente, de revalorar su 
capacidad intelectual, de plantear sus inconformidades y reclamos iniciales por abrirse nuevos espacios, por acceder a una mejor preparación." (ALVARADO, 1999, s/p).

Maria Concepcion Gimeno Flaquer nasceu na Espanha em 11 de dezembro de 1850, na localidade Alcañiz. Teve uma boa educação que propiciou sua formação como professora, uma das poucas profissões abertas ao sexo feminino. Nesse país cresceu e teve privilegiadas relações. Ainda solteira, aventurou-se como empresária no universo jornalístico ao ser fundadora, proprietária e diretora de La Ilustración de la Mujer, em 1873, além de que vinha publicando em outros espaços de colaboração feminina, como no caso do Almanach das Senhoras (TORREZÃO, 1873), um empreendimento da portuguesa Guiomar Torrezão que chegou a vários países, inclusive nas Américas. Casou-se apenas aos 29 anos, idade considerada avançada para as mulheres na época, com Francisco de Paula Flaquer, em 11 de julho de 1879, um homem de letras operante no universo jornalístico (PINTOS, 2016). Segundo Cláudia Montero, “a edición fue un oficio que les permitió [as mulheres] no sólo ingresar al campo cultural, sino adquirir una profesión que les permitió subsistencia y desarrollo personal." (MONTERO, 2019, p. 94)

Ao longo de sua vida soube valorizar relações, inclusive com poderes políticos e intelectuais, o que foi fator importante na sua trajetória profissional e resultou em distinções e medalhas de governos americanos, como foi o caso do México e da Venezuela. Segundo Margarita Pintos,

Busca relaciones y apoyos para contribuir con acciones específicas a la eliminación social de todas las formas de opresión. Cada relación que establece se convierte en un eslabón para encontrarse con otras mujeres. Por eso recibe numerosas invitaciones y recorre doce países latinoamericanos de la mano de asociaciones feministas y a través de los contactos con las logias masónicas (PINTOS, 2016, p. 9)

Maria Concepcion Gimeno Flaquer residiu em dois países americanos, México e Argentina, assim como visitou cerca de outros dez, sendo tais experiências primordiais para suas produções (PINTOS, 2016). No México, lançou a revista El Album de la Mujer, em 8 de setembro de 1883, a qual circulou até 1890, fruto de suas proveitosas experiências editoriais, dessa vez com o incentivo e apoio do marido. As principais defesas veiculadas naquelas páginas estavam relacionadas ao direito à educação e ao desenvolvimento profissional das faculdades 
femininas, isto é, ocupações fora do espaço doméstico e com valorização dos pares, fossem ao frequentarem cursos e universidades ou ao ocuparem instituições e associações catedráticas devidas. Em suma, apenas uma boa formação intelectual propiciaria às mulheres o exercício de uma profissão, seguido da independência econômica, ideias fundamentalmente relacionadas ao incipiente feminismo ocidental e liberal que começava a ganhar forma naquele final do século XIX.

Do mesmo modo, as páginas da revista foram um espaço de divulgação intelectual importante para além das reivindicações, trazendo os mais diversos tipos de produções literárias, desde novelas, crônicas, poesias, investigações científicas, históricas e modas. Isso se justifica pelo fato de que comumente essas mulheres não obtinham destaque nos meios hegemônicos da atividade intelectual de seu tempo, levando-as à criação de espaços alternativos, como no caso das revistas. Além disso, as publicações de caráter mais doméstico, com assuntos considerados de menos importância, como culinária, moda, casamento, permaneceram no horizonte de suas publicações, uma vez que nesse contexto as pautas de cunho mais reivindicatório foram sendo colocadas gradativamente numa estratégia editorial de sucesso.

A família Flaquer retornou à Espanha em maio de 1890. Os sete anos que residiram em solo mexicano propiciaram que a jornalista espanhola estabelecesse redes feministas e intelectuais importantes, fundamentais para a circulação de ideias em âmbito transnacional. Uma materialização dessas relações foi a publicação de El Album Ibero Americano, uma revista lançada em 1890 na Espanha trazendo um compilado de publicações literárias de diversas escritoras latino-americanas, contribuindo para estreitar relações entre os dois continentes. As publicações se finalizaram em dezembro de 1909, totalizando 803 exemplares com os mais diversos assuntos. ${ }^{10}$ Importante ressaltar que ainda que as publicações de cunho feminista aparecessem, o impresso igualmente cedeu espaço a outras discussões importantes no âmbito literário, inclusive ao propiciarem que homens também assinassem os textos, não sendo uma revista exclusiva de publicações de mulheres. Talvez essa escolha da intelectual espanhola tenha

\footnotetext{
${ }^{10}$ A grande maioria das edições encontra-se sob guarda da Biblioteca Nacional da Espanha, disponíveis para acesso digital em: http://hemerotecadigital.bne.es/results.vm?q=parent $\% 3 \mathrm{~A} 0003028610 \& \mathrm{~s}=0 \&$ lang=es
} 
associação com as redes intelectuais e a circulação que desejava alcançar com suas discussões, fazendo, por exemplo, com que o debate intelectual com a participação de mulheres se ampliasse mundialmente.

Essas relações foram das mais diversas, uma vez que intelectuais, jornalistas e editoras, homens e mulheres de países latino-americanos colaboraram com seus textos. O objetivo era exatamente estreitar relações quanto às discussões naquele final do século. A circulação da revista iniciou-se no dia 7 de agosto de 1890, na cidade de Madri, destacando que suas origens não eram novas. A experiência de Gimeno Flaquer frente à revista El Album da Mujer (1883), no México, foi destacada pela redação para apontar as origens da revista em solo madrileno. O álbum surgia como uma segunda fase da publicação mexicana. Por conseguinte, tal fato aconteceu porque antes de o casal deixar o país americano, Maria Concepcion Gimeno Flaquer conseguiu do governo recursos para a continuação do periódico na Espanha, que durou até aproximadamente 1895 (ALEGRE, 2021). Segundo Ferrari, a América "surge en el pensamiento de Gimeno como fuente para la modernización de España, en un intercambio guiado por un anhelo regenerador, paralelo al deseo de regeneración social de la mujer" (FERRARI, 2020, p. 92)

Ao que tudo indica, a revista circulou na Espanha e em países latino-americanos, chegando também à França no início do século XX (ALEGRE, 2021), o que dá indícios do alcance intelectual das ideias nela veiculadas. Em suas páginas pregava-se o modelo de sociedade burguesa, ligado ao projeto de modernidade, cada vez mais em prática em fins do século XIX. Segundo Ana Ivonne Diaz, "los conceptos de modernidad, ciudadanía y género fueron surgiendo, aunque de manera tímida, en revistas de corte femenino que, al igual que las otras, también tuvieron un gran desarrollo" (DIAZ, 2000).

A circulação desses impressos transnacionalmente propiciou que os seus escritos se disseminassem grandemente. Essas mulheres, então, começaram a compartilhar as produções umas das outras, sendo que muitas se identificaram com o que vinha sendo escrito por suas companheiras das lides. Em 14 de fevereiro de 1891, por exemplo, a chilena Delfina Maria Hidalgo publicou uma poesia dedicada à intelectual uruguaia Adela Castell, descrita como uma 
“distinguida poetisa del Uruguay". Na ocasião, ela escreveu que "As brisas de tu suelo, /Llegando hasta mi patria./ Trajéronme tus notas,/ Tus notas regaladas." (El Álbum Ibero-americano, 1891, Edição 6:68). A homenagem aponta o conhecimento de Hidalgo pelo trabalho exercido nos círculos intelectuais uruguaios de Castell, inclusive valorizando seu talento frente à qualidade de suas produções. Ambas as intelectuais latino-americanas publicaram seus trabalhos em El Álbum Ibero-Americano, dirigido pela senhora Gimeno Flaquer. A comunicação dessas duas intelectuais, e diversas outras que aparecem, por meio da publicação das revistas dirigidas por Maria Concepcion Gimeno Fraquer, aponta para uma solidariedade intelectual no compartilhamento dos textos, assim como confere a importância dos impressos para colocá-las em contato umas com as outras.

Nesse entremeio de idas e vindas entre México e Espanha, as ideias da espanhola também chegaram em solo brasileiro, ocasião em que seus textos foram anunciados nas páginas de $A$ Família, um periódico de cunho feminista que tinha na sua redação Josephina Álvares de Azevedo. Ainda que o nome da brasileira não tenha figurado nas páginas de El Album Ibero Americano, a aparição da espanhola nas páginas brasileiras corrobora com a circulação de seus textos em diversos países, indicando a notabilidade intelectual alcançada por ela entre suas companheiras americanas. No dia 12 de janeiro de 1889, um sábado, as brasileiras foram agraciadas com um extenso texto de Maria Concepcion, intitulado "O Estudo". Na circunstância, a escritora fez uma exposição em que defendeu a necessidade da instrução feminina, muito embasada nas argumentações postas de que isso tornaria as mulheres melhores para a sociedade, ora como mães e esposas. Interessante observar que os papéis de gênero permaneceram muito bem delimitados nos textos de grande parte dessas mulheres ao longo do século XIX. Embora se colocassem como postulantes à igualdade entre homens e mulheres, nesse contexto existiam limites quanto a essa igualdade. Isso pode ser observado na conclusão do referido artigo:

Maridos, se tendes fortuna, ofertai uma biblioteca a vossas mulheres, pois disse um homem de esclarecido talento: que toda mulher que abre um livro encoraja um demônio. Os antigos faziam o sinal da cruz quando se lhes apresentavam o demônio sob qualquer 
forma. Nós, os filhos do século XIX, cremos que o melhor exorcismo para afugentar é um livro A Família, 1889, Edição 7:5). ${ }^{11}$

Os homens continuavam como os mentores, responsáveis por propiciarem condições adequadas para que as faculdades intelectuais dessas mulheres florescessem, isso desde ao ofertarem uma biblioteca em suas casas, como apontado, até inserirem suas mulheres em círculos intelectuais. Ainda que o sujeito universal masculino, heteronormativo e branco, não fosse diretamente questionado em suas bases, as incipientes reivindicações dessas mulheres foram centrais para os movimentos que vieram postumamente, não podendo em hipótese alguma serem desconsideradas.

A jornalista brasileira seguirá publicando alguns textos da intelectual espanhola, uma forma de divulgar suas produções para as leitoras do periódico A Família, que regularmente publicava textos de profissionais das letras de diversos lugares do mundo. O curioso é que as publicações são encontradas tanto no período que Gimeno Flaquer viveu no México como após retornar à Espanha, mostrando que Josephina Azevedo seguiu acompanhando a trajetória de Maria Concepcion e de suas revistas. Em 1891, ocasião em que ela já se encontrava na Espanha, Josephina Álvares Azevedo publicou na edição de 12 de março, na primeira página, um texto homenageando a espanhola e suas lides intelectuais, contemplando as leitoras brasileiras com uma gravura com o seu retrato. Segundo suas palavras:

Indo para o México, sentiu bafejar-lhe o sopro do jornalismo libérrimo da América e tomou a sua responsabilidade a redação da importante revista El Album de la Mujer, prestando a nossa causa o concurso ingente de que é capaz o prestígio de sua poderosa pena. [..] É uma das representantes do nosso sexo que mais os distinguem nas letras, no convívio da sociedade e no templo caricioso e edificante da família. (A Família, 1891, Edição 98: 1)

A incipiente profissionalização dessas mulheres mundo afora, junto às ideias feministas que ganhavam cada vez mais adeptas, foram cruciais para o estabelecimento de uma sociabilidade intelectual, em que essas mulheres buscavam reafirmar suas aptidões umas nas outras, buscando exemplos em diversos espaços. Não conseguimos afirmar com precisão se

${ }^{11}$ A Família. São Paulo. Ed.7, p.5. 12 jan. 1889. 
Josephina Azevedo e Maria Concepcion Gimeno Flaquer de fato trocaram correspondências ou mantiveram um contato mais íntimo uma com a outra, nem ao menos se os textos foram enviados ou retirados e traduzidos pela jornalista brasileira, todavia, o fato de terem circulado nas páginas de $A$ Família, além da divulgação de seu retrato, valida a notabilidade da espanhola em diversos espaços latino-americanos, inclusive no Brasil.

Novamente, agora em 1910, a família Flaquer retornou às terras da América Latina, dessa vez na Argentina, onde ficaram até o falecimento de ambos. A chegada da intelectual se deu no contexto em que o feminismo latino-americano se encontrava mais efervescente, sendo terreno fértil para um diálogo com países vizinhos. A espanhola vinha mantendo relações com o país argentino há algum tempo, desde aproximadamente 1882, quando encontramos colaboração da jornalista em periódicos. Outra indicação também pode ser vislumbrada em um de seus ensaios de 1904, Mujeres de raza latina, momento que dedicou sublime conhecimento da história da Argentina, desde a ditadura de Juan Manuel Rosas (1835-1852) até os principais nomes de escritores e escritoras atuantes naquele país (FERRARI, 2020).

Segundo Margarita Pintos, biógrafa de Maria Concepcion Gimeno Flaquer, ao pisar na Argentina ela desempenhou um papel fundamental na difusão intelectual e feminista, isso porque empreendeu várias viagens por países latino-americanos com o objetivo de realizar conferências e ampliar a sociabilidade por meio de associações e clubes estritamente femininos (PINTOS, 2016). O contato da espanhola com suas companheiras da América Latina advém desde finais do século XIX, circunstância que se empenhou em estreitar relações por meio das páginas de suas revistas, que provavelmente se estendeu até o deslocamento pessoal ocasionado por suas estadias nos respectivos países. Até o seu falecimento, em 1919, a espanhola permaneceu na Argentina, logo, suas relações pessoais e profissionais foram por muito tempo tecidas nesse espaço do Sul Global. Neste lugar, ela pôde contribuir sumariamente para a discussão do incipiente feminismo que começava a ganhar forma no entresséculos, buscando se atentar para as especificidades regionais das reivindicações de suas companheiras intelectuais latino-americanas.

\section{Margaret Randall e o papel da revista bilíngue El Corno Emplumado}


Como pudemos perceber pela intensa circulação e atuação de Maria Concepcion Gimeno Flaquer no continente latino-americano, este vinha sendo um local de trocas e discussões entre mulheres intelectuais desde o século XIX. Acreditamos que essa circulação de ideias formuladas por mulheres foi também contribuinte para um debate feminista na região. Indo mais além, e no esteio dessa atuação, pretendemos tratar também da trajetória intelectual da poetisa estadunidense Margaret Randall (1936), que, assim como Gimeno Flaquer, optou por atuar a partir do Sul global. Randall também escolheu viver no México e dali passou a organizar uma série de relações artísticas e literárias no meio intelectual. Sendo assim, compreendemos que tanto Gimeno Flaquer quanto Randall romperam com as amarras de gênero impostas em seus respectivos contextos e passaram a desempenhar um papel central enquanto agentes e articuladoras de importantes redes intelectuais transnacionais.

Não por acaso, ambas atuaram em efervescentes trocas intelectuais desde a Cidade do México, sendo as cidades locais propícios para a ação intelectual e circulação de ideias, em consonância com o que afirma Ángel Rama (1998). Margaret Randall se mudou para o México em 1961, quando iniciou sua trajetória de vinte e três anos vividos na América Latina, voltando aos Estados Unidos apenas em 1984. Contudo, devido aos limites de espaço deste artigo e à análise proposta de diálogo entre ambas as intelectuais, definimos como recorte sua atuação no período que de 1962 a 1969, momento em que fundou e editorou a revista El corno emplumado/The plumed horn, em parceria com o poeta mexicano e seu então companheiro, Sérgio Mondragón. Com este recorte, daremos foco ao papel que exerce por meio da revista, o que nos aproxima também da atuação de Maria Concepcion Gimeno Flaquer, que igualmente se deu a partir da editoração, articulação e publicação em jornais e revistas no século XIX. Assim, avançamos na análise proposta a respeito do papel desempenhado pelas mulheres enquanto intelectuais que atuaram no espaço público e na conformação de redes intelectuais que tornaram possíveis trocas entre escritores/as e artistas do Sul e do Norte global.

$\mathrm{O}$ contexto de mudança de Randall se deu em meio à Guerra Fria e na tensão provocada pela recente vitória de Cuba (1959), motivada, segundo ela mesma (RANDALL, 2015), pelo sentimento de hostilidade no ambiente artístico dos Estados Unidos, período que ela identificou 
como seu despertar político frente ao sufocamento imposto, ainda, pelo McCarthismo ${ }^{12}$. Outro elemento determinante para Randall deixar os Estados Unidos foi sua condição de mãe solo e as implicações dos trabalhos de cuidados que ela tinha de desempenhar em uma sociedade que ela considerava hostil e que sobrecarregava as mulheres com o trabalho doméstico e os cuidados dos/as filhos/as ${ }^{13}$ :

Me fui a México más que nada porque era madre soltera y creí que iba a poder pasar más tiempo con mi hijo. Estando en New York, quería tener un hijo, y escogí como padre el poeta estadounidense Joel Oppenheimer, pero no teníamos una relación estable ni nada por el estilo. En los años ' 60 había muy pocos servicios para madres solteras. (RANDALL [entrevista], 2019, s/p) [Tradução nossa]

Alguns anos antes foi mais fundo na questão ao relacionar diretamente sua mudança com o cotidiano da maternidade:

[...] não era fácil, ser uma mãe jovem que tinha desistido da universidade para me sustentar junto com meu filho. A cidade [Nova Iorque] era dramaticamente carente de serviços sociais. Eu pensei: bem, talvez eu já tenha tido tudo que podia de Nova Iorque. $\mathrm{Eu}$ era aventureira e acreditava que a vida no México poderia ser mais fácil. E foi. Eu tinha empregada doméstica e mais tempo livre numa sociedade que era divertida e gostava de crianças. O México também era política e culturalmente iluminado ${ }^{14}$. (RANDALL, 2015, s/p) [Tradução nossa]

Desde o México, Randall prontamente se inseriu no meio intelectual e artístico do país. Nos encontros que ocorriam na casa de seu conterrâneo Philip Lamantia ${ }^{15}$, convivia com poetas de diversos locais do continente latino-americano e estadunidense. Nesse espaço de trocas entre poetas do Norte e do Sul global, surgia a dificuldade de boas traduções que, de fato,

\footnotetext{
12 "I was also experiencing a political awakening common to many of my age, young people who felt a restless nonconformity stifled by the chill of McCarthyism, even if we had been born too late to be direct victims of that repressive siege."

${ }^{13}$ Essa questão é ainda atual e presente em todo o mundo, sendo amplamente discutida na literatura feminista, contexto no qual gostaríamos de destacar o trabalho da brasileira Heleieth Saffioti, "A mulher na sociedade de classes" (1969).

14 "But it wasn't easy, as a young woman who had given up on college to support my child and myself. The city was dramatically lacking in social services. I thought: well maybe I've gotten what I can from New York. I was adventurous and believed life in Mexico might be easier. It turned out to be. I had household help and more flexible hours in a society that was laid back and loved children. Mexico was also politically and culturally illuminating."

${ }^{15}$ Parte da chamada "Geração Beat".
} 
conseguissem abarcar a subjetividade das poesias de seus colegas, foi quando decidiu fundar a revista intercontinental e bilíngue com Mondragón. O objetivo era traduzir a língua, mas, antes de tudo, a cultura, intenção presente no título da publicação, el corno/the horn, uma referência direta aos instrumentos de sopro usados no jazz estadunidense, enquanto emplumado/the plumed faz referência às plumas do deus asteca Quetzalcoatl. Assim, desde o nome, estava definido o objetivo que se queria alcançar com a revista: estabelecer um diálogo horizontal entre as produções artísticas e intelectuais do Norte e do Sul, a partir do princípio da troca e da igualdade entre cada um que ali publicava, propiciando traduções de novas/os poetas e também de nomes consagrados, fomentando a circulação principalmente da poesia. Com El Corno, rompiam com o fluxo colonial da cultura e da intelectualidade.

Por isso, o projeto da revista tinha um papel questionador sobre qual poesia seria difundida e divulgada no mundo. Queriam promover poetas de diferentes lugares, colocá-los/as em diálogo entre si e com outros/as artistas reconhecidos/as e iniciantes em suas trajetórias. Autodefinia-se como uma revista de poesia, artes e cartas e assim foi se consolidando no meio intelectual. O espaço das cartas cresceu, tornando-se um lugar para que intelectuais que se encontravam em diferentes partes do globo se comunicassem e discutissem sobre a conjuntura de seus países, sobre o sentido da arte, sobre revolução, sobre o "homem novo". O financiamento da revista acontecia a partir de muito esforço individual de seus colaboradores, fosse a partir de doações, atividades coletivas, como, por exemplo, as declamações de poemas que buscavam arrecadar dinheiro, ou a luta por anúncios e patrocínios oficiais de instituições ligadas ao governo mexicano. Sendo assim, Randall e Mondragón, apesar de amenizarem e, no primeiro editorial, declararem que a revista não tinha um objetivo político, já delineavam seu caráter continental com a intenção de ampliarem o diálogo entre as "duas Américas” (EUA e América Latina).

Os trabalhos de financiamento, editoração e publicação da revista eram feitos apenas pelo casal Randall e Mondragón na própria casa em que viviam, o que incluía a tradução de diversos poemas e a publicação de textos autorais. Nos oito anos de existência, o periódico nunca deixou 
de ser publicado, tendo atrasado uma única vez (nos 16 números analisados ${ }^{16}$ ), em meio aos cuidados domésticos e com os/as outros/as três filhos/as que tiveram juntos. Não havia entre eles uma hierarquia editorial ou de produção, ambos se responsabilizavam por todas as tarefas, como é retratado por alguns artistas nas cartas que remetem a passagens pela casa dos dois. Assim, o papel desempenhado por Margaret Randall não era desqualificado ou colocado em segundo plano pelo seu gênero. Pelo contrário, como podemos perceber pela seção de cartas, várias tarefas eram direcionadas diretamente a ela, reconhecendo seu papel intelectual e como editora. Os editoriais de cada revista, que eram escritos em espanhol e em inglês, não eram traduções literais de uma língua para outra, mas sim um espaço em que manifestaram suas posições, e muitas vezes divergências, políticas. Também notamos que Randall publicou poemas em diversos números da revista, atuando enquanto poeta e intelectual.

Devido às características fundacionais e que foram legitimando El Corno ao redor do globo, hoje nos arriscamos a dizer que essa publicação assumiu uma proposta e função de decolonizar a arte e, principalmente, a poesia. Com diversas sessões, publicaram poemários específicos de poemas argentinos (número 5 e 13), poesia do Equador e do Uruguai (número 6), de Cuba, Colômbia e Nicarágua (número 7 e a última também no número 15), do Peru (número 9), poesia indígena e de povos tradicionais das Américas (número 10), da Venezuela (número 11), finlandesa e russa (número 14) etc. Segundo Randall (2020), publicaram mais de setecentos artistas, de trinta e cinco nacionalidades diferentes, além de diversos livros pela editora que veio a se chamar El Corno Emplumado Press. A revista cresceu e em 1962 tinha uma tiragem de 2000 exemplares, já em seu trigésimo primeiro número, em julho de 1969, seus 3500 exemplares foram entregues a representantes na Argentina, Brasil, Chile, Costa Rica, Guatemala, Paraguai, Peru, Porto Rico, Cuba, Equador, Uruguai, Venezuela, Estados Unidos, Inglaterra, Índia, Alemanha, Austrália, Canadá, Suécia e Espanha. Assim, a revista cumpria sua função de circulação ao redor do mundo, colocando o Sul e o Norte global num espaço comum, compartilhado e de trocas, onde artistas, poetas e intelectuais consagrados/as, locais e novos,

\footnotetext{
${ }^{16}$ Até o momento da redação deste artigo, havíamos analisado 16 dos 31 números da revista, ou seja, seus quatro primeiros anos de existência, entre 1962 e 1965.
} 
dividiam e dialogavam, circulavam pelos continentes, colocando no mundo a voz da diversidade das Américas, criando uma rede transnacional.

O espaço de cartas tomou um certo destaque por facilitar o diálogo entre intelectuais na efervescente década de 1960, quando puderam trocar impressões artísticas, formular sobre o papel público de intelectuais e provocar intensos debates políticos desde suas realidades locais até o debate sobre a revolução. Foi por meio da editoração e publicação de tal revista que Randall se inseriu e atuou ativamente no cenário artístico e intelectual latino-americano e internacional. A partir de El Corno, estabeleceu contatos ao redor do mundo todo e, principalmente, na América Latina, favorecendo o diálogo com aqueles/as que mantinha relação desde os Estados Unidos, estabelecendo, juntamente a Mondragón, uma importante rede de intelectuais a partir do periódico ${ }^{17}$. Dentre esses contatos, gostaríamos de ressaltar a relação que estabeleceu com o nicaraguense Ernesto Cardenal, importante figura da Revolução Sandinista, padre e poeta, que posteriormente se tornou Ministro da Cultura do governo Sandinista ${ }^{18}$.

No decorrer de seus números, a revista adotou uma postura de maior intervenção na conjuntura política, o que culminou com seu final forçado ao adotar um discurso em defesa dos/as estudantes de Tlatelolco e de oposição ao governo do PRI ${ }^{19}$. Para Gabriela Ibarguen, em meados da década de 1960, El Corno passou a ser um importante meio de comunicação, em que vozes silenciadas podiam se expressar, circular e debater entre diferentes intelectuais ao redor do mundo,

[...] una voz en medio del silencio promovido por los gobiernos para mantener el orden social. Las notas del corno dieron voz a los acallados. En otras palabras, a los manifestantes en contra de la guerra de Vietnam, a quienes estaban a favor del Movimiento de los Derechos Civiles, a aquellos que apoyaron la Revolución Cubana y,

\footnotetext{
${ }^{17}$ Infelizmente não encontramos trabalhos que mapeiem qual foi, qual a dimensão e a importância da rede intelectual articulada a partir de El Corno Emplumado.

${ }^{18}$ Em 1980 foi convidada pelo governo sandinista, para realizar um trabalho testemunhal no país, sobre a transformação da vida das mulheres com o processo de luta sandinista, assumindo a posição de publicitária do Ministério de Cultura da Nicarágua, cargo que exerceu entre 1981 e 1982, a convite do poeta e então ministro, Ernesto Cardenal. A partir de 1983, atuou no Foreign Press Center, em Manágua, vivendo na Nicarágua até 1984 ${ }^{19}$ Uma série de manifestações estudantis que buscavam negociar com o governo do PRI e que levaram a uma greve estudantil, com apoio de outros setores populares, nas vésperas dos Jogos Olímpicos de 1968, o que finda com um grande massacre por parte das Forças Armadas, a mando do governo, na Praça de Tlatelolco/Praça das Três Culturas, dez dias antes da abertura das Olimpíadas. Milhares de pessoas foram presas e centenas mortas.
} 
en general, a los que se atrevieron a criticar un régimen opresor. (IBARGUEN, 2017, p. 23)

Dessa forma, a revista desempenhou um importante papel ao colocar em circulação visões e opiniões divergentes das narrativas hegemônicas, "en gran medida El Corno Emplumado formó parte de otra historia, fuera de la oficial, que, aún hoy —cincuenta años después - no puede ser silenciada." (IBARGUEN, 2017, 0.23). Porém, apesar do papel político crescente El corno pode ser reconhecido como importante meio de difusão de vozes silenciadas, apesar da baixa publicação mulheres entre as/os colaboradores da revista. Dentre poemas, prosas e ilustrações, 429 foram de autoria masculina, enquanto apenas 83 são assinadas por mulheres ${ }^{20}$, o que nos indica os limites da participação das mulheres nas publicações e no meio intelectual, limitada mesmo em uma publicação editorada por uma mulher. Apesar de defender abertamente a luta por direitos civis na década de 1960, a reflexão acerca da necessidade de ampliar o espaço para publicação de mulheres não fez parte das reflexões de Margaret Randall nesse período. Posteriormente, em sua autobiografia, Randall (2021) destaca a força das tensões e da opressão às mulheres no período pós-guerra, principalmente na década de 1950, momento em que se considera como "pré-feminista". Adotando uma postura crítica a partir de reflexões posteriores ao período em que editorava a revista, reconhece que na época de El Corno, a questão de gênero não era uma preocupação sua - inclusive não encontramos o debate de gênero nas discussões estabelecidas por meio da revista -, reproduzindo uma visão imposta de exclusão das mulheres do espaço público e do meio intelectual:

O último número de El Corno foi publicado no verão de 1969 (31 de julho de 1969), logo antes da segunda onda do feminismo explodir na cara da consciência Ocidental. Quando solicitávamos e selecionávamos os trabalhos para o jornal, a gente nunca pensava no gênero daqueles que haviam produzido. Como quase todo mundo naquele tempo, nós estávamos imersos na ideia patriarcal de que a maioria dos bons escritores e artistas eram homens, com algumas mulheres que ocasionalmente "escreveram ou pintaram como um homem". Quando eu olho a revista hoje, a falta de consciência de gênero aparece para mim. Acredito que tenha sido nossa maior falha. (RANDALL, $2015, \mathrm{~s} / \mathrm{p})^{21}$

\footnotetext{
${ }^{20}$ Fizemos a contagem geral de trabalhos publicados, e não de autores/as, sendo assim, algum/a artista aparece com publicação em mais de um número da revista.

${ }^{21}$ Tradução nossa: "El corno last issue appeared in the summer of 1969 (\#31, july 1969), ust before feminism's second wave exploded across the face of Western consciousness. As we solicited and selected work for the journal,
} 
O que podemos apreender a partir dessa reflexão feita por Margaret Randall 46 anos após o fim da revista é que a inserção das mulheres no meio intelectual não se deu de forma natural, não foi algo facilmente aceito pelo meio, mas sim fez parte de um processo de luta e de ressignificação do papel das mulheres mais amplo, na esfera pública, como parte e resultado do alargamento do debate feminista. Esta "falha" é reconhecida por ela desde 1975, quando, ao falar sobre o término da revista, reforça como a publicação estava diretamente imbricada pelas questões colocadas naquele tempo, sendo uma destas a ausência da "consciência feminista":

\begin{abstract}
Margaret Randall no omite lo que ella considera fallas dentro de la publicación. Entre éstas menciona la notable ausencia de mujeres entre la nómina de colaboradores: “...nós realmente pensávamos que poderíamos ser irmãos (A gente não pensava sobre nos tornarmos irmãs. Nós eramos poucas mulheres, uma minoria numa maioria de homens. Nossas pretensões intelectuais levavam em conta essa proporção - consciência enquanto mulheres não era parte de nós naquela época)". ${ }^{22}$ (IBARGUEN, 2017, p. 14)
\end{abstract}

Com uma postura crítica em relação à ausência de uma consciência feminista no período de El Corno, sabemos que os debates e as publicações de caráter feminista e que levavam em conta a condição da mulher já eram uma realidade no território latino-americano desde o século XIX. Margaret Randall encontra o feminismo e se coloca, enquanto intelectual, a seu serviço logo após o fim da revista em Cuba, na Nicarágua e no Peru, onde trabalhou oficialmente para seus respectivos governos realizando um importante ofício de coleta de testemunho de mulheres. Foi a partir daí que passou a ter sua trajetória intelectual a serviço da realidade das mulheres latino-americanas e com os debates feministas que estavam acontecendo, para além dos debates que ocorriam no Norte global no período que ficou conhecido como segunda onda do feminismo 23. Contudo, a ausência de um debate feminista explícito e de um maior incentivo à publicação de

we never thought of the gender of those who produced. Like almost everyone else at the time, we were mired in the patriarchal idea thet most good writers and artists were men, with the occasional woman who wrote or painted like a man'. When I look at the magazine today, this lack of gender consciousness stares back at me. I belive it was our greatest failing."

${ }_{22}$ Tradução nossa: “...we really thought we could be brothers. (We didn't think then, about being sisters. We were a few women, a minority among mostly men. Our intellectual pretensions took care of that ratio - women's consciousness was not part of us then)".

23 "Para alguns autores e autoras, dentre eles Luciano Fabbri, devemos ter cuidado ao pensar o feminismo latino-americano com base na visão de ondas. Essa perspectiva divide o processo de emancipação das mulheres em 
mulheres na revista não diminui a importância de termos Randall como uma mulher que, rompendo com o papel de gênero imposto, criou e editorou uma revista com relevante circulação mundial, contribuindo para os debates intelectuais de sua época.

Assim, ressaltamos que apesar de não carregar nos primórdios a tônica do debate sobre o ser mulher, e o ser mulher na América Latina, Randall desempenhou um papel central na articulação de intelectuais latino-americanos/as e de outras partes do mundo, desde El Corno que, muito mais que uma revista, acabou se consolidando como um espaço de encontros e de trocas, que desconstruiu o espaço intelectual dominado por uma produção Ocidental e masculina. Por meio da revista, levou principalmente a poesia latino-americana aos quatro cantos, posicionou-se politicamente e atuou na esfera pública. Além disso, promoveu encontros e diálogos, rompeu papéis de gênero ao escrever, publicar, editar e conduzir a revista. Foi Randall quem aproximou El Corno Emplumado do espírito revolucionário dos anos 1960. Três anos após o início da revista, em que ela e Mondragón afirmaram no editorial que El Corno não seria uma revista de política, Randall afirmou no editorial do número 15 que: "Esta é uma revista de poesia. Mas, como cabe a todos os seres humanos, nós fazemos nosso protesto."24

\section{Considerações finais: as mulheres como intelectuais e as redes transnacionais}

Se pensarmos na atuação de mulheres intelectuais ao longo da história, um dos poucos nomes que nos vem à cabeça é o da francesa Simone de Beauvoir. Isso porque sua vida "se tornou um símbolo de sucesso para gerações de mulheres que não se contentavam mais com sonhar por meio dos sonhos dos homens" (KIRKPATRICK, 2020, p. 365). Ainda que o seu nome tenha alcançado notabilidade mundial, inclusive ao conseguir subsistência com seu trabalho, uma utopia para a grande maioria, as dificuldades em sua vida não foram poucas. Por muito tempo associou-se seu trabalho às sombras de seu companheiro Jean Paul Sartre, alguns se arriscaram a

\footnotetext{
três ondas, definidas a partir de uma visão Eurocêntrica [...] Segunda onda: nas décadas de 1960 e 1970 emerge o chamado feminismo radical, que buscava a politização dos corpos das mulheres e a aceitação de sua sexualidade. Aqui, surge o uso do termo patriarcado, é também quando surge a pílula anticoncepcional, que permite maior liberdade sexual para as mulheres e a possibilidade de se planejar a maternidade. As duas principais frases de mobilização são: 'O pessoal é político' e 'Não se nasce mulher, torna-se mulher'.” (GONTIJO, 2019, p. 131-132)

${ }^{24}$ Tradução nossa: "This is a magazine of poetry. But, as befits every human being, we make our protest."
} 
dizer que ele seria a verdadeira mente produtora por trás das produções da filósofa. Hoje sabemos que, pelo contrário, foi Beauvoir que não teve reconhecida grande parte de sua contribuição à produção de Sartre.

Este exemplo, imerso nas discussões intelectuais de meados do século XX na Europa, permite elencarmos uma infinidade de questões que são centrais para as discussões aqui propostas. Simone de Beauvoir foi uma intelectual branca, das classes altas, que produziu no Norte global, do epicentro do conhecimento hegemônico que era Paris, no efervescente século $\mathrm{XX}$, motivo de sua circulação e sucesso mundial em outros espaços. Ainda assim, enfrentou embaraços na sua trajetória, o que nos faz interpelar sobre as muitas outras intelectuais que não tiveram a mesma oportunidade. As personagens aqui apresentadas, Maria Concepcion Gimeno Flaquer e Margaret Randall, com todos os privilégios de nascimento, posição social, relações, cor e letramento, não são lembradas de maneira equivalente, e isso corrobora com a importância das epistemologias feministas para problematizar a escrita da história e sua hegemonia masculina.

Do mesmo modo, assim como os debates de gênero apareceram bem timidamente nas discussões propostas e aqui analisadas, tanto por Gimeno Flaquer quanto por Randall, para Beauvoir esse tema também só veio a se tornar uma questão tempo depois. Isso se explica pelo fato de que historicamente as mulheres tiveram que driblar os percalços e as barreiras masculinas para que conseguissem acessar determinados espaços, e o universo intelectual foi um deles. Nesse espaço, para ganharem legitimidade, muitas vezes tiveram de se furtar a antigos pactos masculinos, que tinham como prática a exclusão de sujeitos subalternizados. Conquanto, a atuação dessas mulheres, circulando constantemente em espaços masculinos, materializa as reivindicações feministas no acesso ao âmbito do trabalho, reafirmando uma agência em busca de seus anseios. Muitas mulheres estavam presentes e resistiram à imposição de certas ideias e comportamentos. No século XIX, a título de exemplo, a ideia de igualdade entre homens e mulheres, juntamente às maiores reivindicações por direitos, foi vista como uma utopia distante e inalcançável, fazendo com que muitas mulheres, mesmo que suscetíveis a sanções, se utilizassem de suas penas para escreverem, ainda que timidamente, contrárias à exclusão sistemática do sexo feminino em todos os âmbitos sociais. 
Maria Concepcion Gimeno Flaquer, espanhola de nascimento e uma intelectual atuante nos meios impressos de sua época, optou por manter relações constantes com as latino-americanas, inclusive ao residir por períodos consideráveis no México e na Argentina, bem como realizar viagens constantes a outros países. Em finais do XIX, em grande parte desses países, empreendimentos editoriais com direção e colaboração femininas já eram uma constante no cenário social. As iniciativas que, no começo, haviam surgido como uma alternativa contra-hegemônica às imposições de gênero colocadas em suas vidas, aos poucos foi se transformando em uma oportunidade de profissionalização nas letras e um sinal de independência. Devido a isso, muitas delas buscaram focar suas produções nos gêneros literários em voga no momento, desde a poesia até as crônicas e romances, além dos assuntos mundanos da imprensa informativa.

As contradições entre a posição de intelectual e as imposições de gênero continuam ao longo do tempo. Como vimos, Randall também enfrentou particularidades ao ser uma mulher poeta e editora. Avançando cronologicamente até meados do século XX, contexto que se insere Margaret Randall, ainda que o movimento feminista tenha alcançado mais espaço e obtido algumas vitórias, sobretudo no que tange aos direitos civis, as dificuldades de debater pautas feministas abertamente ainda permaneciam como um problema, inclusive no seio da esquerda revolucionária ${ }^{25}$. Nesse sentido, é importante destacarmos o quanto as sociabilidades intelectuais formadas a partir da publicação em espaços comuns, como foi o caso dos periódicos, contribuíram para que essas mulheres ocupassem um espaço que lhes era historicamente negado, criando locais em que vozes silenciadas pudessem circular e chegar a outros lugares, adentrando o debate político e atuando na esfera pública. No caso de Maria Concepcion Gimeno Flaquer, sua trajetória contribuiu para a criação de uma consciência coletiva sobre atuação profissional feminina nas letras, sendo que as relações pessoais travadas foram importantes. No caso de

\footnotetext{
25 Debatemos esse assunto ao tratarmos da atuação e trajetória da intelectual nicaraguense Gioconoda Belli no contexto da Revolução Sandinista na Nicarágua, nas décadas de 1970 e 1980. Para saber mais: GONTIJO, Stella Ferreira. "Hasta que seamos libres": feminismo e Revolução Sandinista nas obras de Gioconda Belli (1972 - 1993). Dissertação (Mestrado). Elisa de Campos Borges, orientadora. Universidade Federal Fluminense, Niterói, 2019.209 f. Disponível em: <https://www.historia.uff.br/stricto/td/2361.pdf>.
} 
Margaret Randall, essa atuação contribuiu para a criação de uma consciência coletiva da atuação intelectual de artistas e poetas latino-americanos/as. Em ambos os casos, as intelectuais estabelecem redes que colocaram sujeitos excluídos em circulação Norte-Sul, questionando o padrão hegemônico colonial da produção do conhecimento Ocidental.

Uma estratégia comumente utilizada foi o trânsito internacional, por meio da qual se possibilitou que essas mulheres circulassem suas ideias com pares mundo afora. Ao fazerem isso, tornavam-se conhecidas, ao mesmo tempo que teciam relações profissionais que contribuíram significativamente para seus empreendimentos editoriais. Tanto Maria Concepcion Gimeno Flaquer quanto Margareth Randal, cada qual inserida em seu contexto histórico, tiveram uma importante atuação e articulação de redes transnacionais, publicando temas literários de seus contextos específicos. Segundo Adriane Costa e Cláudio Maíz (2018), as redes intelectuais tiveram um papel central durante o século XIX e XX, momento em que "aqueles que dominaram a letra e, com isso, ganharam um status de autoridade." (COSTA; MAÍZ, 2018, p. 8). Ainda segundo esses autores, o caráter transnacional dessas redes é importante para pensarmos na “centralidade dos deslocamentos físicos para o movimento das ideias na cultura" (ibid, p. 9), o que consideramos útil aqui para pensarmos na circulação de ideias feministas e latino-americanas produzidas desde a América Latina, pois, como afirma Bárbara Weinstein (2013, p. 19), “a abordagem transnacional, justamente por mostrar a alta permeabilidade das fronteiras (nacionais, regionais etc.) e a intensa circulação de corpos, ideias e objetos de consumo, questiona a viabilidade da comparação, especialmente entre nações”. Sendo assim, a partir dessa complexidade, Carlos Henrique Armani (ARMANI apud. COSTA; MAÍZ, 2018, p. 210-211) afirma que

[...] la red puede ser un entrelazamiento de los contextos en cuestión, no porque sean la simple presencia, sino por el contrario, porque ellos son la apertura radical de to do sentido, en el cual el preguntar por su ser implica una inmersión en aquello que él no es. [...] En este sentido, la red intelectual constituida sería un componente contextual que relaciona hechos procesos, lenguajes. 
Assim, essas mulheres, a partir do estabelecimento dessas redes transnacionais, romperam com as barreiras do Estado-nação a partir dos seus trabalhos editoriais, por meio de diálogos comuns a respeito das desigualdades de gênero, do imperialismo norte-americano ${ }^{26}$, usando-se dessa relação de diálogo para retirarem do Norte global a hegemonia da produção do conhecimento, da cultura, da produção artística e literária. Nessa perspectiva, este artigo também visa corroborar com as produções historiográficas que vão no mesmo sentido, combatendo uma visão positivista da história. Por isso, assim como afirma Barbara Westein (2013, p. 16), em diálogo com os estudos subalternos, a "abordagem 'transnacional' surgiu e ofereceu um novo modo de visualizar as interações e intercâmbios no meio hemisférico ou até global.”, em busca de compreender que, "certas figuras e grupos em toda parte do Novo Mundo contribuíram com os discursos da modernidade, e essa noção procura extinguir a antiga, mas persistente dicotomia 'El Norte Moderno/El Sur Tradicional'.' (ibid, p. 18).

O acesso a esses espaços não foi uma tarefa fácil, pelo contrário, necessitou de uma luta constante e coletiva para que fossem aceitas nas redações e instituições específicas da classe intelectual. A igualdade de posições, no entanto, ainda permanece uma luta do movimento feminista, que tem sido sanada, em parte, devido à entrada de mulheres nas universidades e as epistemologias feministas, que unem teoria e prática social. Ao mesmo tempo, esse acesso não está e não foi possível a todas as mulheres devido às diversidades de raça, classe e sexualidade. Portanto, poucas foram aquelas que conseguiram enfrentar os óbices do ofício, não podendo desconsiderar as condições sociais, em que majoritariamente destacam-se as brancas, de classes média e alta dos países do Norte global. Ainda que o gênero tenha dificultado o acesso, as confluências de raça e classe dificultaram que outras conseguissem chegar aos mesmos espaços, sobretudo se pensarmos a experiência latino-americana da colonização, em que indígenas e africanas sofreram com a opressão colonial de escravização de seus corpos, discussão que

\footnotetext{
26 "Para Wendy Kozol, la crítica al imperialismo y al racismo europeu y norteamericano, así como los desafíos de las desigualdades de género, fueron determinantes en el desarollo de la Historia Transnacional." (PRADO, 2012, p.19)
} 
recentemente tem se tornado um eixo central nas epistemologias feministas, como resultado de reivindicações de intelectuais negras, decoloniais e pós-coloniais.

\section{Fontes:}

AZEVEDO, Josephina Alvares. A Família: jornal literário dedicado à mãe de família. São Paulo/Rio de Janeiro (1888 a 1894). Edições disponíveis em: $<$ http://memoria.bn.br/DocReader/docreader.aspx?bib=379034\&pesq=\&pagfis $=1>$ FLAQUER, Concepcion Gimeno. El Album Ibero americano. Madri (1891 a 1909). Disponível para acesso em: $<\underline{\text { http://hemerotecadigital.bne.es/results.vm?q }=\text { parent } \% 3 \mathrm{~A} 0003028610 \& \mathrm{~s}=0 \& l a n g=\mathrm{es}}>$

FLAQUER, Concepcion Gimeno. El Álbum de la Mujer: Periódico Ilustrado. México (1883 a 1890).

MONDRAGÓNS, Sergio; RANDALL, Margaret. El corno emplumado. Open Door Archive. Disponível em: $<$ https://opendoor.northwestern.edu/archive/items/browse?collection=5 $>$ Acesso em: 7 ago. 2021. Revistas consultadas: n. 1 - janeiro 1962, n.2 - abril 1962, n.3 - julho 1962, n.4 - outubro 1962, n.5 - janeiro 1963, n.6 - abril 1963, n.7 - julho 1963, n.8 - outubro 1963, n.9 janeiro 1964, n.10 - abril 1964, n.11 - julho 1964, n.12 - outubro 1964, n.13 - janeiro 1965, n.14 - abril 1965, n.15 - julho 1965, n,16 - outubro 1965.

RANDALL, Margaret. Remembering El Corno Emplumado, 2015. Disponível em: $<$ https://opendoor.northwestern.edu/archive/exhibits/show/el-corno-emplumado-hemispheric/rem embering-el-corno-randall $>$ Acesso em: 1 ago. 2021.

. Margaret Randall: "El feminismo siempre ha sido una herramienta para examinar el poder". [Entrevista concedida a] Mabel Bellucci. Latfem, 2019, s/p. Disponível em: $<\underline{\text { https://latfem.org/margaret-randall-el-feminismo-siempre-ha-sido-una-herramienta-para-exami }}$ nar-el-poder/> Acesso em 3 ago. 2021.

. I never left home: poet, feminist, revolutionary. Durham: Duke University press, 2020.

TORREZÃO, Guiomar. Almanach das Senhoras. Terceira Edição. Lisboa: Tipografia de Souza e Filho, 1873.

\section{Referências bibliográficas:}

ALEGRE, Ana I. Simón. Prensa, publicidad y masculinidades através del periódico madrileño Álbum Ibero-Americano (1890-1909). Revista História e Memória. Tunja, Colômbia, p. 29-75. 2021.Disponível 


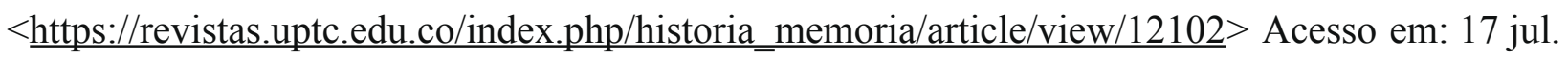
2021.

ALVARADO, Lourdes. La prensa como alternativa educativa para las mujeres de principios del siglo xix. In: (org) AIZPURU, Pilar Gonzalbo. Familia y educación en Iberoamérica. El Colégio de Mexico, 1999.

ARMANI, Carlos Henrique. Historia intelectual, contextos de la escritura y redes. In.: COSTA, Adriane Vidal; MAÍZ, Cláudio. Nas tramas da "cidade letrada": sociabilidade dos intelectuais latinoamericanos e as redes transnacionais. Belo Horizonte: Fino Traço, 2018.

COSTA, Adriane Vidal; MAÍZ, Cláudio. Introdução. Nas tramas da "cidade letrada": sociabilidade dos intelectuais latinoamericanos e as redes transnacionais. Belo Horizonte: Fino Traço, 2018.

DEVÉS-VALDÉZ, Eduardo. Redes intelectuales en América Latina: hasta la constitución de una comunidad intelectual. Santiago do Chile: Colección Idea; Segunda [Epoca; Instituto de Estudios Avanzados; Universidad Santiago de Chile, 2007.

DIAZ, Ana Ivonne. El álbum de la mujer. Periodismo femenino: El primer paso hacia la modernidad y la ciudadanía. Revista Desacatos, n.3. México, 2000. Disponível em: $<$ http://www.scielo.org.mx/scielo.php?script=sci arttext\&pid $=$ S1607-050X2000000100009> Acesso em: 10 jun. 2021.

FERRARI, Marta Beatriz. Concepción Gimeno y el Álbum Ibero-Americano: Argentina como fuente para la modernización de España. Diablotexto Digital 8 (2020), 79-97. Disponível em: $<$ https://ojs.uv.es/index.php/diablotexto/article/view/17771 > Acesso em 15 jul. 2021.

GOMES, Ângela de Castro; HANSEN, Patrícia Santos. Intelectuais mediadores: práticas culturais e ação política. Civilização Brasileira: Rio de Janeiro, 2016.

HARDING, Sandra. A instabilidade das categorias analíticas na teoria feminista. In: (org) HOLANDA, Heloísa Buarque. Pensamento feminista. Conceitos fundamentais. Rio de Janeiro: Bazar do Tempo, 2019.

HOOKS, Bell. E eu não sou uma mulher? Mulheres negras e feminismo. Rio de Janeiro: Rosa dos Tempos, 2020.

. Mulheres negras: moldando a teoria feminista. Revista Brasileira de Ciência Política,

no16. Brasília, janeiro - abril de 2015, pp. 193-210. Disponível em: $<$ https://www.scielo.br/j/rbcpol/a/mrjHhJLHZtfyHn7Wx4HKm3k/abstract/?lang=pt $>\quad$ Acesso em: 8 ago. 2021. 
IBARGUEN, Gabriela Silva. Texto, contexto e índices de El Corno Emplumado (1962-1969). [Mestrado]. El Colegio de San Luis, San Luís Postosí. 481p., 2017.

KIRKPATRICK, Kate. Simone de Beauvoir: uma vida. São Paulo: Planeta do Brasil, 2020.

LERNER, Gerda. A criação do Patriarcado: história da opressão das mulheres pelos homens. São Paulo: Cultrix, 2019.

MC CLINTON, Anne. Couro imperial: raça, gênero e sexualidade no embate colonial. Campinas, SP: Editora UNICAMP, 2010.

MIGNOLO, Walter. Desobediência epistêmica: a opção descolonial e o significado de identidade em política. Cadernos de Letras da UFF - Dossiê: Literatura, língua e identidade, n.34, p. 287-324, 2008.

. Colonialidade: O lado mais escuro da modernidade. Revista Brasileira de Ciências Sociais.Vol. 32 n. 94, p.01-18, junho/2017. Disponível em: $<$ https://www.scielo.br/j/rbcsoc/a/nKwQNPrx 5Zr3yrMjh7tCZVk/abstract/?lang=pt $>$ Acesso em: 10 ago. 2021.

MONTERO, Cláudia. Trayectorias de las editoras profesionales del fin del siglo XIX en Chile. Estudos filológicos, n.64, Valdivia, 2019. Disponível em:

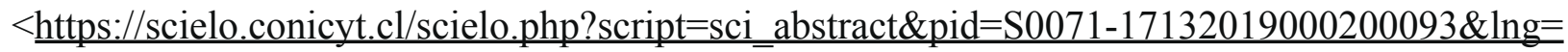
pt\&nrm=iso $>$ Acesso em: 21 jul. 2021.

PINTOS, Margarita. Concepción Gimeno de Flaquer: feminista poliédrica. Filanderas. Revista Interdisciplinar de Estudios Feministas. 2016, p.7-26. Disponível em: $<\underline{\text { http://www.cervantesvirtual.com/obra-visor/concepcion-gimeno-de-flaquer-feminista-poliedric }}$ a-971300/html/95b26fca-78d8-4aal-a138-a87fbcb562b4 6.html > Acesso em: 1 ago. 2021.

PRADO, Maria Lígia Coelho. América Latina: História comparada, histórias conectadas, história transnacional. Anuario de la Escuela de Historia, Rosário, n. 24, p. 9-22, 2012. Disponível em: < http://rephip.unr.edu.ar/handle/2133/3719>.

PRATT, Mary Louise. "No me interrompas": las mujeres y el ensayo latinoamericano. Debate Feminista, 21, abril, 2000, p.70-88. Disponível em: $<$ https://debatefeminista.cieg.unam.mx/df ojs/index.php/debate feminista/article/view/260 $>$ Acesso em 20 jul 2021.

PRIETO, Maria Isabel Hernandez. Escritores hispanoamericanos en "El Album Ibero-Americano" (1890-1899). Documenlación de las Ciencias de la Información, n.16. Madrid, Editorial Complutense, 1993. Disponível em: 


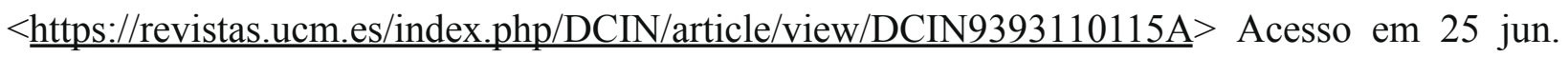
2021.

RAMA, Ángel. La ciudad letrada. Motevideo: Arca, 1998.

RAGO, Margareth. Epistemologia feminista, gênero e história. In: Pedro, Joana; Grossi, Mirian (orgs.) Masculino, feminino, Plural. Florianópolis: Editora Mulheres, 1998.

RICHARD, Nelly. A escrita tem sexo? In: RICHARD, Nelly. Intervenções críticas. Belo Horizonte: Editora UFMG, 2002.

SAID, Edward W. Representations of the intellectual: the 1993 Reith lectures. New York: Pantheon Books, 1994.

SCOTT, Joan Wallach. Gênero: uma categoria útil de análise histórica. Educação \& Realidade. Porto Alegre, vol. 20, n. 02, jul./dez. 1995, pp.71-99. Disponível em:

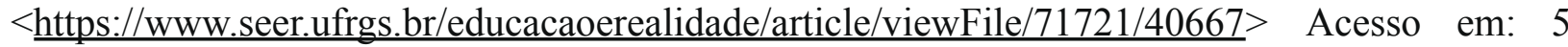
mai. 2021.

SMITH, Bonnie. Gênero e História: homens, mulheres e prática histórica. São Paulo: EDUSC, 2003.

TELlES, Norma. Autor+a. In: JOBIM, José Luís [org.]. Palavras da Crítica: Tendências e Conceitos no Estudo da Literatura. Rio de Janeiro: Imago, 1992.

- Encantações: escritoras e imaginação literária no Brasil, século XIX. São Paulo: Intermeios, 2012.

TILLY, Louise A. Gênero, História das Mulheres e História Social. Revista Cadernos Pagu. Campinas, vol. 3, 1994, p. 29-62. Disponível em: $<$ https://periodicos.sbu.unicamp.br/ojs/index.php/cadpagu/article/view/1722/1706> Acesso em: 17 ago. 2021.

XAVIER, Giovana. Você Pode Substituir Mulheres Negras Como Objeto de Estudo por Mulheres Negras Contando Sua Própria História. Rio de Janeiro: Editora Malê, 2019.

WEINSTEIN, Bárbara. Pensando a história fora da nação: a historiografia da América Latina e o viés transnacional. Revista Eletrônica da ANPHLAC, n.14, p.13-29, 2013. 